\title{
A Topographic Field Trip of Washington, D.C.- A Cartographic Multimedia Application
}

\section{Introduction}

The U.S. Geological Survey (USGS) has produced "A Topographic Field Trip of Washington, D.C.," a multimedia CDROM that uses topographic maps to tour Washington, D.C. Although designed for the middle school grade level, it can also be used to teach introductory topographic map reading skills to any level.

Two versions of " $A$ Topographic Field Trip of Washington, D.C.," are available. The first version, for Macintosh ${ }^{\circledR}$ systems only, was developed and produced as a prototype with educational resources funds and is available free of charge.

The second version, for dual platforms, Macintosh ${ }^{\circledR}$, and Windows ${ }^{\circledR}$ systems, is a sales item. The dual platform version contains improvements in content and navigational capabilities.

\section{Contents}

This CD-ROM is an innovative application that displays digital map data to teach students how to read and interpret spatial information. Students relate the map to the real world through the use of sounds, graphics, text, animation, and interactivity. The graphic user interface resembles a video game controller and functions as an interactive map legend.

Mapping tools are provided to navigate the Nation's Capital. With these tools, students are able to accomplish the following:

- measure distance and direction,

- determine latitude and longitude,

- learn map symbols,

- look at digital orthophotos,

- determine elevation,

- find descriptive information on post cards, and

- examine historical maps.
The field trip begins with a "landing at Washington National Airport." After exploring a topographic map, students will be required to record answers to predetermined questions in a journal. By correctly answering the questions, students earn Metrorail farecards that are used to navigate to different areas of the tour. If the tour is not completed in one session, the option is available to return to the same area and continue at a later time. The "Free Tour" option (only available on the dual platform version) allows navigation to different areas without having to answer questions. The "Information Room" gives information about how to use the CD-ROM and how to use the mapping tools. Journal questions appear at each tour stop, and when all of the tour areas have been visited and the questions answered correctly, students are presented with a ticket to tour the White House.

\section{Hardware Requirements}

\section{Macintosh@ Systems}

- System 7 or greater

- At least $8 \mathrm{Mb}$ of RAM (16 Mb recommended)

- 256-color, 13-inch monitor, or larger

- Macintosh-compatible CD-ROM drive

- $\quad 15-20 \mathrm{Mb}$ of free disk space

- Startup Instructions: Double-click "TFTMAC" projector icon in the TFT folder on your desktop

\section{Windows@ Systems}

- 486-33 Mhz

- At least $16 \mathrm{Mb}$ of RAM

- Windows 3.1x or Windows 95

- 2X CD-ROM drive

- 256-color, 13-inch monitor, or larger

- Windows-compatible sound card
- 15-20 Mb of free disk space

- Startup Instructions: Go to the CD drive on your computer and doubleclick either the "TFT95.exe" for Windows 95 or the "TFT31.exe" for Windows 3.1; or drag the "TFT95.exe" projector icon to your desktop to create a shortcut.

\section{Information}

The Macintosh-only version is free of charge while supply last. The dual platform version (Macintosh $\AA$ and Windows ${ }^{\circledR}$ ) is available for $\$ 11.50$ plus a $\$ 5.00$ handling charge per order if purchased by mail. Both versions are available over the counter from a USGS Earth Science Information Center or by mail from:

\section{U.S. Geological Survey \\ Information Services \\ Box 25286 \\ Denver, CO 80225-0286}

For information on other USGS products and services, call 1-888-ASK-USGS, use the Ask.USGS fax service, which is available 24 hours a day at 703-6484888 , or visit the general interest publications Web site on mapping, geography, and related topics at mapping.usgs.gov/mac/isb/pubs/pubslists /index.html.

For additional information, visit the ask.usgs.gov Web site or the USGS home page at www.usgs.gov.

Any use of trade, product, or firm names is for descriptive purposes only and does not imply endorsement by the U.S. Government. 